\title{
The measures religious cults took in front of COVID-19: weakness or diligence?
}

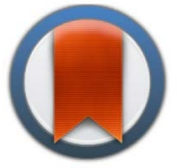

ARTICLE INFO

\section{Article history:}

Received 28 February 2020

Received in revised form 17 May

Accepted 20 May 2020

Available online 30 June 2020

doi: 10.18638/dialogo.2020.6.2.14

\section{Keywords:}

Covid-19; pandemic; religion; religiousness; medical care; critical measures; digital; online; crisis; fundamentalism; Holy Communion; contradictions; social conflicts;

\author{
Rev. Cosmin-Tudor CIOCAN, PhD \\ The Faculty of Theology, \\ Ovidius University of Constanta \\ Romania \\ cosmin.ciocan@univ-ovidius.ro
}

ABSTRACT

While spreading wide-world, the new coronavirus Sars-CoV-2 made changes in many social departments of our society on levels we never thought about and messes with all our cultural habits. Thus, we witnessed that the religious denominations took into consideration changes without precedent in their cultic history and thus dogmatic as well concerning the actual threat of Coronavirus. We saw for example the RomanCatholic Church who suspended all masses here and there [1] at first or banned the crucial gestures in rituals [to suspend the distribution of Holy Communion from the Chalice [2], to distribute the Eucharist preferably into the hands of the faithful, and to avoid the physical contact from a peaceful handshake, to forego ash crosses on forehead, to suspend placing water in holy water fonts at the entrance of churches, that the churchgoers "refrain" from kissing or touching the cross for veneration, or even cancellation of masses]. We witnessed Buddhist temples and Protestant churches around Korea [at first] and beyond that have also suspended religious gatherings, and so on. In my case, the Romanian Orthodox Church did the same thing [3], but in a controversial way, firstly making some recommendations for its believers [e.g. not to kiss public icons in Churches, but their indoor ones, and receive Holy Communion with teaspoons for single-use]; afterward same Church reconsidered these recommendations and withdrew its decision [perhaps at the pressure of civil fundamentalists]. How can we qualify all these measures and, moreover, the withdrawal on behalf of religious believers, as weakness, populism, diligence, assuming the human limits, or...something else? What would be the correct and coherent answer religion(s) should assume in this particular regard, and especially what are the reasons to qualify it in a way or another? 


\section{INTRODUCTION}

The new Coronavirus [Sars-CoV-2, 20192020] that spread all over the world into a pandemic outbreak took humanity by surprise and has placed every social system out of service. Even if we are talking about transport and traveling, about economy and industry, education and academic meetings, tradeandimport,medicalandpharmaceutical systems, all were overwhelmed and ready to collapse in front of this tiny, invisible, and unintentional organism. One of the global systems that had to face significant changes in order to survive and overpass this crisis is the religious one, who, of all, stands the most rigid and impassive until this crisis with regard to civil society demands of corrections. This motionless and impassiveness was always the main response of the religious phenomenon to all requirements the civil, secular society had previously demanded when there were changes in the civilization, changes that also required wave of changes in religion(s). The 'resistance to change' of religions has always been openly manifested, and the fundamentalist cluster of each religion had been fiercely opposed to any adaptation. Of course, this 'adaptation' has always been made eventually, but it took decades and sometimes centuries to do it. However, as we shall see further on, what the secular society failed to achieve from religious leaders through an overwhelming and long-lasting pressure, an unintelligent microorganism has succeeded it, as if it was sent to test our limits and to shame our audacity which had encompassed us, as it was done before, at the tower of Babel (Genesis 11:9). The strongest point demanded by all authorities was towards all human activities to concur in stopping the spread of the pandemic. Dr. Nathalie MacDermott, National Institute for Health Research academic clinical lecturer King's College London, says: "The change of term does not alter anything practically as the world has been advised for the last few weeks to prepare for a potential pandemic, which has hopefully been taken seriously by all countries. The use of this term however highlights the importance of countries throughout the world working cooperatively and openly with one another and coming together as a united front in our efforts to bring this situation under control."[4]

\section{THE PROBLEM: RELIGIOUS RESPONSES TO} THE PANDEMIC OUTBREAK CHALLENGES

The big question concerning the actual topic is: why is there a problem for religious communities with regard to the civil measures taken in this pandemic outbreak? Moreover, the thing is that even if we knew so few things about this new Coronavirus (real origin, manifestation, bodily targeting, population framefocusing, medical weapons to fight against etc.), the most important 'weapon' to fight against its spreading was considered to be the social distancing. The thing is that religious rituals and gatherings are, almost everywhere, the core facts to prove religiousness. Giving them up would mean for believers giving up proving religiousness, equaling with apostasy for the fundamentalists. Therefore, this kind of measure would be regarded as giving up faith, God. Thus, someone would instead consider it more relevant to keep proving their religiousness in spite of the threat caused by COVID19. We can address this threat as any other one that created martyrs who gave up their freedom of choice to life over proving their religiousness, or we can give up on it and try to adapt in order to survive as a society.

By the time I finished writing this article (end of April) may not be the worst scenario of this pandemic, and there are still many people, groups, and institutions that disagree and hold fast to common-sense measures to contain the spread of Coronavirus. We saw 
along with the spreading of this pandemic how religious communities have faced it and made or not changes in their daily religious routine. This situation is due moreover since for Christianity, this outbreak concurs with the fasting period for Easter, a period of increasing religious presence in churches, looking for more religious gatherings, and increasingly spending time in churches. In essence, all of these habits consist of contraventions to the virus's spreading measures. We know [at 11.03.2020] that the best chance humanity has to 'deal' with this pandemics is to try to contain as much as possible the spread of Covid-19, and the best measure of doing that is staying indoors. As we 'speak' Italy is closed for already a couple of days, declared as a country 'in quarantine' and the drastic measures they took to 'contain' [as if it would be the case for this in their situation any-longer since Italy has now over 10,000 confirmed cases and it continues to grow and stay on pallposition [on 5.4.2020, they have 15,362 deads].

Some social agencies have said that the lack of concurrence on behalf of religious communities in this situation proves only a lack of compassion, understanding and civic sense. For others, equally important, doctors and scientists, religiousness seems to be the only valid option most people should turn to these days. I have heard so many people involved in saving this unsalvageable situation, mayors, doctors, people of State, that have asked those at home through the video a message similar to "now is the moment that you turn to God; stay indoors for us and pray, pray, pray, so that we can see all exit from this crisis'. All medical systems from countries in 'the red zone' collapsed in facing this outbreak. Thus, doctors have seen the unseen, their human powers unspeakable widened, receiving unexpected aid, and thus asking for more. I heard stories about that scattered all over the 'first line' of fighting, and they ask for more help from those deemed to be closer to God.

"Believers worldwide are running afoul of public health authorities' warnings that communal gatherings - the keystone of so much religious practice - must be limited to combat the virus' spread. In some cases, religious fervor has led people toward cures that have no grounding in Science; in others, it has drawn them to sacred places or rites that could increase the risk of infection."[5] There are so various 'healing' solutions offered by diverse religious communities all over the world as a response to the desperate calls came from infected people, overwhelmed doctors, terrified stretchers, scared authorities and so forth, that these 'original' solutions did not delay to flourish. "In Myanmar, a prominent Buddhist monk announced that a dose of one lime and three palm seeds - no more, no less would confer immunity. In Iran, a few pilgrims were filmed licking Shiite Muslim shrines to ward off infection. Furthermore, in Texas, the preacher Kenneth Copeland braided televangelism with telemedicine, broadcasting himself, one trembling hand outstretched, as he claimed he could cure believers through their screens."[6]

\section{MEASURES TOOK BY DIVERSE RELIGIOUS COMMUNITIES}

The religious practices of hundreds of millions of people are undergoing profound changes in response to the COVID-19 pandemic caused by a new coronavirus. The crisis has prompted many religious leaders to appeal to their followers to not only take safety precautions but also to embrace their spirituality to help confront the health, social, and economic challenges ahead. We have witnessed a broad range of changes in the religious practices of daily routine, from wearing protective masks due to the coronavirus outbreak and using alcohol 
gel as they take part in a ceremony, giving blessings or confessions from a distance, to significant changes in religious rituals, pilgrimage and celebrating Holidays. Many religious authorities are closing places of worship or limiting public gatherings. In an extraordinary gesture in February, Saudi Arabia banned foreign arrivals and halted visits to Mecca and Medina for umrah, a religious pilgrimage that Muslims can undertake at any time of year. Riyadh also briefly shuttered the Great Mosque in Mecca and the Prophet's Mosque in Medina for disinfection. Many mosques have canceled Friday services, and calls to prayer in countries such as Kuwait and Malaysia have been altered to tell people to pray from home. Buddhist New Year celebrations, which often bring thousands of people together for public water fights and other events, have been canceled across South Asia. ${ }^{[7]}$

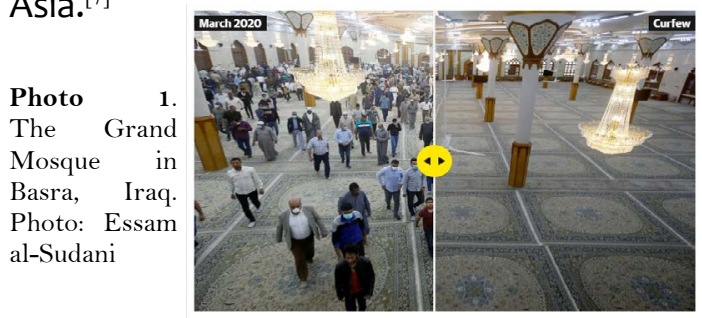

The whole Roman Catholic Church proved resilience and collaborate with the authorities and end up even by changing core rituals and alter others, previously considered immutable and unchangeable, as it is the case with congregants receiving Holy Communion $^{[8]}$. Still, other Churches were more resistant and averse to requirements.

The conservative Eastern Orthodox traditionalists from Tbilisi to Athens have argued against church closures or altering their centuries-old custom of sharing the bread and wine with a common spoon for Holy Communion. On the other hand, there are so many religions who took extreme, unprecedented measures to contain and help the secular society slower the outbreak.
All over the world, we witnessed important global religious events or local ones curtailed, rescheduled, or even canceled. In April, most of the world's major religions have festivals involving large gatherings of people. The Easter is on April 12 for Roman Catholic Church (a week later for Eastern Orthodox churches); Passover begins on April 8 for Hebrew; Rama Navami, an important Hindu festival, is on April 2, while the Sikh festival of Vaisakhi is a few days later. The Islamic holy month of Ramadan begins around April 23. ${ }^{[9]}$ At first, all seemed to take place, with special conditions thou, but still be on. Then, day by day, with the magnitude of the pandemic, they were all canceled successively. In the beginning, people were advised that all gatherings outside of work and school will be limited to 100 persons in the first decade of March; afterward, they were limited to 10 people or less with effect from March 26, 2020, $23^{59}$ hrs to April 30, 2020. "During this period, places of worship may remain open for essential rites (e.g., weddings and funerals) and private worship, subject to a cap of 10 persons at any one time and with the precautionary measures listed in the Annex. As much as we understand the desire of friends and acquaintances to pay their last respects and give comfort to families in their grief, we ask religious leaders to advise their followers on the need to minimize physical interactions even during funerals and wakes. The limit of 10 persons at any one time does not apply in workplace situations in places of worship where religious and administrative staff/volunteers are performing their duties (e.g., providing pastoral services, setting up live streams of religious services). However, the number of workers involved should be kept to a minimum and limited to essential duties. Those who can telecommute from home should do so."[10]

Another of the few crucial cancelations we witnessed these days is the closing of the Mecca from April 4. "The coronavirus 
outbreak disrupted Islamic worship in the Middle East as Saudi Arabia on Wednesday banned its citizens and other residents of the kingdom from performing the pilgrimage in Mecca, while Iran canceled Friday prayers in major cities."[11] That decision alone disrupted travel for thousands of Muslims already headed to the kingdom and potentially affected plans for this year for millions more ahead of the fasting month of Ramadan and the annual hajj pilgrimage. The other major important cancelation we can talk about is The Church of the Nativity in the biblical city of Bethlehem that was closed indefinitely from Thursday, March 5. $^{[12]}$

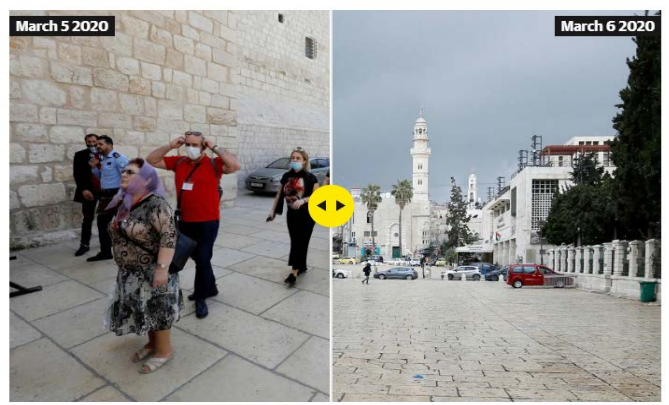

Photo 2. The Church of the Nativity, regarded as the birthplace of Jesus, is closed over fears of coronavirus. https://edition.cnn.com/2020/03/06/world/religionmodify-traditions-coronavirus-trnd/index.html

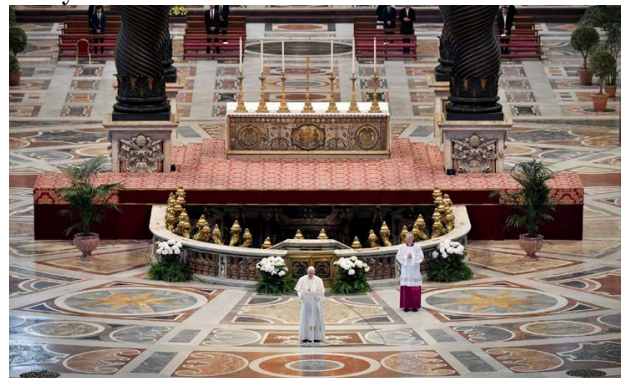

Photo 3. Pope Francis reads his Easter message during Mass at St. Peter's Basilica in Vatican City on Sunday, April 12, 2020. https://www.nbcnews. $\mathrm{com} / \mathrm{news} /$ world/pope-gives-easter-address-emptybasilica-warns-against-selfishness-during-n 1182226

The Church of the Holy Sepulchre, believed to be the site of Jesus's crucifixion and burial, was closed more than two weeks ago; the heavy wooden doors of the Church were last shut during Easter in 1349, while a plague known as the Black Death raged ${ }^{[13]}$. Even the Easter for both Romano Catholic Church and Orthodox ones were shadowed by the absence of believers, which made obsolete and awkward many liturgical acts and gestures. Instead of giving his weekly Sunday greeting at the window in St. Peter's Square in Rome, Pope Francis delivered the Angelus prayer via video link, and even the Vatican's Easter rituals go 'virtual' as Italy battles coronavirus outbreak. Pope Francis gave his annual Easter address Sunday to an empty St. Peter's Basilica as hundreds of millions of Christians celebrating the holiday have been ordered to stay home, and traditions have been upended. "In 2000 years, neither wars nor Nazi occupation, nor plague or any other kind of hardship, have stopped the Pope from celebrating the rituals of the Passion of Christ surrounded by crowds congregating in Rome from every continent. Nevertheless, that is not an option for Pope Francis in 2020 when humanity is under threat from the COVID-19 pandemic." ${ }^{[14]}$ Concerning this, a wonderful adaptation seemed to be a priest took his Good Friday procession to the roof so that church neighbors could participate at a safe distance, from their balconies and windows (see Photo 1). People of the Jewish faith have likewise been taking their Passover celebrations online this week, hosting virtual Seders, and bringing their laptop screens to the table, instead of inviting relatives over to sit down in person (Photo 2).

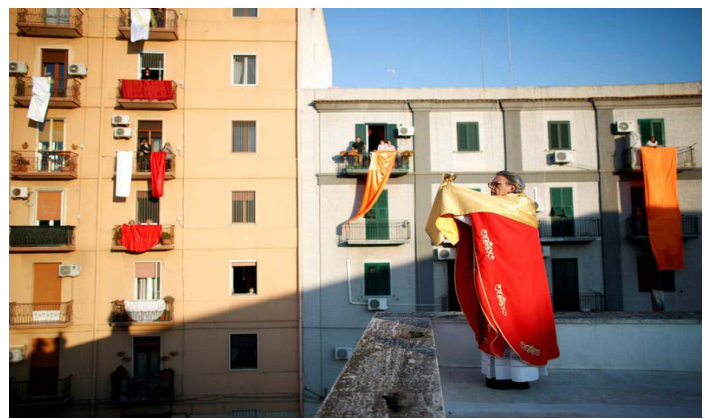


Photo 4. Priest Don Amedeo Basile leads a Way of the Cross procession during Good Friday celebrations on the rooftop of the Maria S.S. Addolorata church, Taranto, Italy, April 10, 2020. ht tps:// w w w. businessinsider.com/photos easter-and-passover-celebrations-during-covid19-outbreak-2020-4\#easter-food-is-also-beingblessed-from-a-distance-in-poland-this-year-6

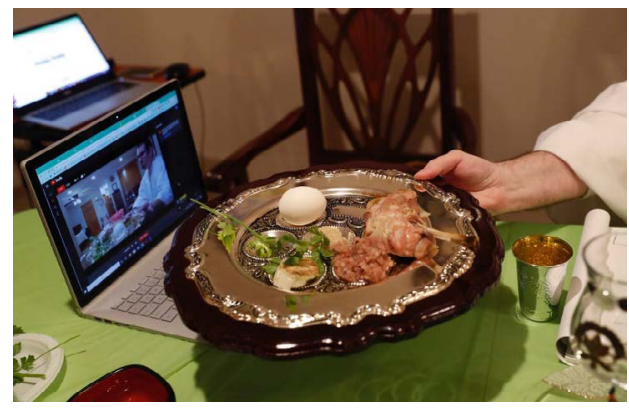

Photo 5. Rabbi Shlomo Segal holds a copy of his Passover haggadah, a guide to the seder and the holiday service, in front of his laptop computer at his home in Brooklyn during the coronavirus outbreak, Wednesday, April 8, 2020, in New York. https://www.businessinsider.com/photos-easter-andpassover-celebrations-during-covid-19-outbreak-20204 \# some-recited-the-haggadah-text-which-guides-theseder-meal-on-screens-this-year-instead-of-face-to-face-19

Is this social demand a unique time in human history, so that we don't know how to act and if our religions' coupe with secular governance can be labeled as apostasy? Not at all! We had previous pandemics and worldwide outbreak and in all religions stood beside society and fought to survive. Examples of such adaptation can be found going all the way back to the plague that swept Italy in 1630 . The world's first ghetto ${ }^{[15]}$ had been created in Venice in the previous century (1516), and by the 17thcentury Jewish populations in other cities, including Padua, likewise lived in restricted areas. It was in the Padua Ghetto that the physician Abraham Catalano worked with local officials to figure out how Padua's Jewish community could celebrate Passover despite the epidemic. Catalano also observed that, during the plague, synagogues were not able to meet their 10-person quorum necessary for services, and that both Jewish people and Christians were finding new ways to worship at home, observing that they "prayed from their windows, or stood by the windows where they could hear prayers," according to Einbinder ${ }^{[16]}$.

\section{A. Religious factions highly disputed some measures until the end}

Efforts to slow the spread of Coronavirus have rekindled a millennium-old debate within Christianity. Should Eastern Orthodox priests use a shared spoon to distribute sacramental bread and wine to churchgoers? The debate has resurfaced amid unprecedented coronavirus measures that are compelling religious institutions around the world to alter some traditional practices temporarily.

In Romania, the chart of taking-retractingretaking measures for the containing of the spread of Sars-Co-V-2 is a little odd and interesting for the study of our topic. In the first place, when the Coronavirus was found at the first Romanian citizen [26.2.2020], the Romanian Orthodox Patriarchy took an ambitious measure to help containing the spread among Romanian citizens [Annex 1, 27.2.2020]. In short, the first set of measures were more than decent and moreover since they were presented as 'recommendations' not as prohibitive rules: to wash hands, stay indoors if feeling sick and watch religious services from TV, do not kiss icons in churches but your particular ones, and topmost to ask for a unique teaspoon for Holly Communion instead of the common one. As usual, fundamentalists and traditionalists have manifested their concern that these measures are only made to let us disregard our faith. In response, the Romanian Patriarchy retracted a few days later these measures, saying that "Communion with another teaspoon we are told of cannot be understood as that during the Holy Liturgy, but a communion with the pre-sanctified Eucharist, called in the people the 'communion for the sick,' which is precisely the Communion for exceptional 
situations. Nor could one imagine that a priest could put in hundreds of teaspoons of the Holy Communion at the specific moment of the Holy Mass. Therefore, the Church does not give up anything but keeps its canonicity unchanged"[17]. With all these statements and retractions and then other statements again, it seems that they are in incapacity either of assuming some requested measures on behalf of secular State, nor to manage the situation, being divided between the requirements of the State and the comments of their followers. However, in the second stage of measures, demanded by the 'State of necessity' decreed and imposed by the State [from 17.3.202], the Orthodox Church finds an explanation enough to comfort its consciousness for taking unprecedented measures, even if only officially. "For moments of crisis, for practical reasons, the Church could find another form of communion, in exceptional situations, which would not embarrass the 'strong' faith of some and not despise the 'weak faith' of others, without departing from the truth of faith and without departing from canonicity."

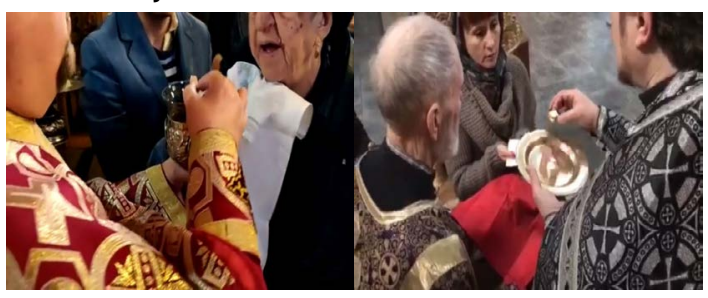

Photos 6, 7. Priest Marga Irimie, Professor of Canon Law at the Faculty of Orthodox Theology in Sibiu-Romania, sharing Holy Communion with his hand. The same method in other particular cases, in the Slovak Church, Copta et.all

This is a charming and diplomatic statement, meant to soothe the curious eyes of authorities, while priests and altar servants where left in the drift, at the mercy of particular situations and decisions, circumstantial. Why do I say this? Because despite this rather particular exposing statement, no higher hierarchy allows priests to interfere and come up with ideas that would fill this liturgical void. Thus, what was meant to allow alternatives to the rite at this moment of anguish for the whole of humanity, rises more misunderstandings and confuses the altar servants that took it as liberty to innovate, to find solutions, alternatives that would be convenient, both for the 'weak faith' as well as for the canonicity. Yet, all those that strived to help the weak, to protect believers from certain malady, because, after all, we are only humans at God's mercy. So, instead of making gestures of bravery and work around the clock to keep the flag up in the faces of people that we, religious leaders, are the carriers of divinity into the world instead of humanly vessels, we should embrace the reality that we are all a big, extended family trying to survive against a common, indiscriminative enemy.

There are, of course, several other similar cases of differences over the practice of delivering Communion using a single spoon dipped in wine for the faithful gathered inside [at first] and then outside churches. "The Eucharist is a core ritual of both Eastern Orthodox and Roman Catholic religious services. It's a ceremony in which priests bless bread and wine, then share it with their congregations. Believers consume the bread and wine as Jesus Christ did at the Last Supper -- the biblical account of the final meal Christ shared with his 12 disciples before his arrest and eventual crucifixion. In most Roman Catholic masses, believers sip the sacramental wine from a common chalice. Eastern Orthodox priests dip the holy bread into the Chalice and use a sacramental spoon to pour winesoaked bread crumbs into the mouths of the faithful." ${ }^{[18]}$ Since they were always in defense of this practice, ultimately, the solution came from the State, which has shut down all public gatherings in response and as an ultimate egress. 
Different Orthodox Churches have responded in kind on this medical recommendation to forbid and temporarily change the use of this 'unique spoon'. Therefore the secular world would believe that there is more immorality in this and had to declare a state of emergency and suspend public gatherings to curb the spread of the Coronavirus. In return, the orthodox clergy banned all services and asked faithful to watch them on TV, so that they would not get themselves in offside with civil people and against State. Georgia's Orthodox Church has rejected calls to stop using the common spoon for Communion. The Orthodox Church of Serbia had the same differences over the common spoon for Holy Communion. However, after its first clerics infected and died, Bishop Milutin Knezevic, 71, who died on Monday, March 30, and two other priests from the Valjevo diocese tested positive for Coronavirus, Orthodox Patriarch Irinej took the same decision to ban all services.

Many Eastern Orthodox Church leaders, however, have agreed to measures aimed at protecting the faithful from catching or spreading the Coronavirus. However, there are still some that had no intentions to do so. "I can tell you with certainty that we will neither close churches nor cancel services [due to the coronavirus]," Metropolitan Ilarion, head of the External Affairs Office of the Moscow Patriarchate, the Russian Orthodox Church's leadership body, said on state-run Rossia-24 TV, Interfax reported on March $14 .^{[19]}$ This seems a matter of faith and doctrine rather than one of the liturgical issues as it should be kept.

Stubbornness and the use of traditional means of 'healing' people are a common practice among many religious communities, of no particular denomination, because we witness such resistance to obedience to medical advice to several cases. As an example, see the Orthodox Church in
Georgia $^{[20]}$ that has taken a unique approach to tackle the coronavirus outbreak, by sprinkling holy water, and its priests refused to alter their rituals and exit in the streets to bless people and comfort them with holy water and prayers.

I would like to call for proving this assertion of mine several cases already confirmed here and there throughout the world about presbyters from different religious denominations that were infected, have infected others, or even died from the actual Sars-Co-V-2 virus. One of notoriety is the case of a US priest who shook hands with more than 500 worshippers infected with virus $^{[21]}$, Reverend Timothy Cole of Christ Church Episcopal in Georgetown positively diagnosed and afterward "canceled, out of an abundance of caution, all activities including church services until further notice," marking the first time the Church has been closed since a fire in the 1800s. By this time [5.4.2020] in Italy, over 90 priests have died by Coronavirus ${ }^{[22]}$, the youngest being at his 45 years. I am sure that this scenario will continue until the pandemic ends in a way or another...

\section{$B$. In this regard, can/should religious communities rely ONLY on faith and take no measures of precautions?}

In the Encyclical, His Eminence Archbishop Elpidophoros of America and the Most Reverend Members of the Holy Eparchial Synod of the Greek Orthodox Archdiocese of America reminds the faithful, "Science and our God-given reason demand that we employ every means available to protect ourselves and our families against the spread of Covid-19 and any other disease. In a crisis such as this, we need to exercise vigilance as a community, lest our churches become points of transmission of the disease." ${ }^{[23]}$

We know and recognize that "God 
uses material means to communicate His blessings and presence to us. The gracefilled presence of Icons, Relics, Holy Water, blessing crosses, objects (such as flowers), and even the blessing hand of a priest, convey to the believer God's grace and energy"[24]. Still, without denying the reality of God's grace and its unseen work upon the world, we should also emphasize that "the same material elements that can convey the blessings of God are also subject to the broken nature of our fallen world."

This conflictual situation between the measures imposed by the secular civil society from the medical area and the resistance of their implementation by certain religious communities was reached for a very simple and obvious reason. It is considered - and this is not a novelty because this impression has always and everywhere thundered the religious area, perhaps with small exceptions - that the religion (to be understood the plural of the religious phenomenon), being revealed and in direct tangency with the divinity, should control and interfere with all fields of public life, not just the spiritual-religious one. This was held many times in history as the shepherd taking care of all needs of his flock, not only feeding and milking the sheeps. In fact, for many centuries and in all religions, the clergyman was the most important personage in the community, holding many public working services besides the religious one, also being the wise teacher, the doctor, and the judge $\mathrm{e}^{[25]}$. All these cumulative functions were on account of revelation and close relation with God, who imposed His servant as the most qualified to act and transmit accordingly to the divine will to people. It is rather strange how these cumulative functions of priests were only concerned to those mind-working trades, leaving the manual work difficult for others, such as fieldwork, pastorate or crafts. That is due to the aforementioned reason that the deity, who is the source of all things and also of all good deeds, should work above all through the religious levers in the world, which would thus lead the religious communities to interfere as I said with all layers of social life, so that all people and in all domains should have the benefit of "divine intervention" at all times.

Thus one forgets the primary reason for which the religion was founded (through the sacrifices brought by Abel and Cain), that of making the relationship between man and divinity functional, a relationship that sin and opposition, the disobedience of man make it discontinuous. Or, precisely this disobedience is taken as a prerequisite for claiming the obedience of all to the Church's love, and for its interference in any field of activity. This false impression has led the Christian Church and religion in general into open conflict with Science they have demonized because it does not accept the revealed "version" on the appearance of the world and of life, and comes with a parallel version of which God does not mention anywhere, so it cannot be true. About this artificial conflict, which does not concern religion and its essence in any way, some theologians have realized and have begun a long and arduous way of "reconciling" the two fields of human knowledge, scientifically and theologically, by assuming a truth that is coherent and appropriate to each field.

\section{CRITERIA FOR CONSIDERING THESE}

\section{MEASURES AS WEAKNESS AND ILLEGITIMATE}

There are still many questions to address religious communities that deny following medical treatments, prescriptions, and refuse to alter rituals for the sake of containing Sarcs-CO-V-2 virus from spreading among religious communities through specific acts of ritual. Is there any real, valuable, and undeniable reason to believe that a virus cannot be spread 
through religious rituals means? Can you offer certainty to all members that religious rituals and acts can provide healing to those affected by the pandemic? Is there any statistic about that infected religious people that got cured after attending Church or receive private Communion in their quarantine; isolate cases do not arise because the incidence of separate cures is very low and random. How can you qualify the fact that there are infected presbyters, and if the rituals do not offer immunity, then why risk the health of others through bravery and stubbornness to improve and adapt the religious rituals, at least temporarily? If stubborn to obey to protective medical prescriptions, why withdraw from the public ministry of the infected clergy: will they not be healed by religious practices and will not protect their believers from contacting the virus? And if to all these questions you answer humanly, that all these acts have worldly consequences, then it is not an unassuming and immature gesture to try to protect an image (i.e., of 'working together with the divinity,' in other words that 'religion has the divine powers and invokes god through its action when and how it desires') that religion should not lose because it would be discredited? However, is it not the role of religion itself to guard, protect, and care for the partisans at all costs, rather than to keep them from lies and selfdenial?

\section{A. Religious resistance to medical treatments}

We are aware of those religious groups such as 'The Followers of Christ', 'Seventhday Adventists'[26] or 'Jehovah's Witnesses' and many others who deny extreme or some medical measures. Their religious beliefs refuse to accept blood transfusions, to receive regular vaccinations and others. For example, the Amish that will not allow heart transplants and, in some cases, heart surgery; Sikhs who disapprove any animal- based products for medical use; Sunni and Shiite Muslims also do not approve of any drugs, medical dressings or implants that contain porcine ingredients; Buddhists may be reluctant to take mind-altering medications; or Evangelical Christian who even avoid flu vaccination. Christian Scientists failing to provide adequate medical care for their children, nor wish to participate as a donor or recipient regarding blood transfusion. Christian Scientists would prefer the body to be kept inviolate unless a post mortem is legally required. Christian Scientists would not normally wish to receive or donate organs. We can see that it is not a singular occurrence, in which case we would be legitimate to deny or question their reason and legitimacy of imposing such measures to their followers. Their reliance on the 'spiritual' healing, rather than medicines, makes a religious example for the religious intransigence against the application of special measures under the conditions of a pandemic and quarantine of the civil society and thus, against the modification of their own religious practices by imposing such measures. There are indeed particular cases, known from Media in which individuals, children or adults, that were forbidden to take medical care that conflicts with the provisions of the religious group of belonging.

\section{CRITERIA FOR CONSIDERING THESE MEASURES LEGITIMATE AND DILIGENT}

The thing with this particular threat is that it is a special one. It maybe sounds like a fallacy ${ }^{[27]}$, but this is its essence, and the main reason all religious communities gave up eventually and considered taking caution measures and change to adapt and survive. In other words, even if in the beginning those measures demanded by the civil society through its medical care system were denied and rejected, facing extinction and moreover shame of their own fear, 
all religious communities adopted these measures with only one spoken or implied motif: all the other ancient threats religious beliefs faced throughout history and made a stand against them even with the cost of human lives [martyrs] were initiated by humans and thus were declared as 'temptations' made in the logical, rational, and voluntary initiative. Now, abhorrent from all other voluntary temptations, this Covid-19 crisis is not proved to be a rational initiative, but a biological threat. Therefore, facing a biological threat for humanity, religions [had to] stand dawn with their resistance to adapt and changed so that they can survive.

Considering the relation between the State(s) and religion (s) we should envision them not as two separate, parallel entities and Institutions - from the point of view that considers them in their institutional organization - but as two circles/sets that intersect or overlap, due to the members they both have and serve, people. As does the religion serves its believers that are also members of the State, the latter have these and others to serve and care for. Thus, their mutual consideration should always be the safety and well-being of the members, above the formal and legislative prescriptions of both these two institutions. What I need to emphasize here is the importance of religions to stand-back with pretentions of resisting to change as the above chapter implies when it is to consider first the safety of their members. I have heard many voices these days from clergy inquiring that 'as the hospitals are open to cure the body of people, should also churches be kept open to the public for curing their souls'? This is not applying to a particular denomination of narrower, community, for this claim is universal between religious leadership of any kind.

Thus, with these two premises raised, to answer to our inquiry [i.e. if it is legitimate for religions to consider taking the measures the secular society demands] we only need to ask few important questions to religion: Can we rely fundamentally and utterly on religion's help in healing infected people? Can religion, whatever we pick, states that it offers complete protection to those that seek shelter against the Covid-19 pandemic [or any other natural threat]? Can one religion or altogether access God's power, gifts or grace invocated so often in liturgical services at all times and to the outcome of creating protection against the natural disasters as this one now is?

To all these questions and many others in kind, the true and ultimate answer is undeniable NO! And this is not an answer that comes from an atheist or an apostate [fallen from the faith, 1 Timothy 4:1], but from a person that believes fully and entirely in God from personal experience. However, also from experience comes to the undeniable truth that miracles happen only in certain moments, for particular persons and only in very mysterious circumstances; they cannot be invoked upon a nation, or rather upon humankind, moreover installed as the 'natural' way of things. From my point of view and experience, miracles are insignificantly the assembling of man's pray with God's will, but barely a lucky meeting of them. This because we cannot summon God or God's grace to do whatever man pleases and needs because "God's Ghost blows wherever He wants" (John 3:8) and "He never asks for permission." Consequently, we cannot assume the role of "God's graces' users" as if we had at our liking and our mercy the divine grace to use and exploit it wherever and however we need. Many rules must be fulfilled for the miracle to occur, but the most likely of these is 'if our request also satisfies the divine plan'. Otherwise it will be absolutely and clearly that divine intervention will not come and the invoker will only be harmed and shamed for his boldness. There is no 
religion, as revealed, 'elected,' gifted or any other blissful attributes may have, that can use and guaranty a on the spot miraculous healing in a personal case, let alone a worldwide intervention. And here I should add a little inside knowledge: if some religious leaders or believers would ever conduct such mission and assume mass healing, then the ultimate and specific feature of religion is broken and violated, for religious target and purpose lies not in bodily healing and connecting to God/ divinity/Supreme being, but in the spiritual care and reconnection. And if some would say in defense that there are miraculous healing sprinkled in all religions, these are for sure side effects of mysterium and only concerning proving the divine presence at that particular time and place, and not the ordinary work and message religion would be 'sent' to give to humans. If otherwise, either the message of religion definitely is in dissonance with its spiritual vocation, or with the message of all other sciences trying to solve the bodily problems of mankind. Nevertheless, since the message of religion cannot be incoherent, and we assume not even antagonistic to the other human disciplines, all aiming at the supreme good of humanity, then we will have to admit as correct only the first hypothesis, that of preoccupying religion exclusively with the spiritual dimension of our existence, leaving in the care of the scientific thinking the research and the assumption of solving world problems - Matthew 22:21, "render to Caesar the things that are Caesar's, and to God the things that are God's". In conclusion, religion cannot assume nor claim the right and role of protecting against natural disasters, healing those fallen under the coronavirus' infection, or any other similar cases.

Of course, amid the pandemic outbreak, it circulates a lot of tendentious messages addressed in such a way that it will catch you offside with both answers, either against the civil measures or against the defended defenders of the faith. E.g., can you get infected if you are going to pray this Sunday to the Church? Are you susceptible of an epidemic threat if seeking spiritual counseling in the Church? Or, did anyone got infected by receiving the Body of Christ? And other similar, but a trained eye can see the tendency in all these because they reveal and use half of truth while masking the other half. For example, praying cannot be the mean of infection but crowding in any closed place, even Church, can be. The 'Body of Christ' is definitely not the leverage by which the infection is transmitted because it is a spiritual presence, but the seen, materials elements, Yes, can be contaminated by any natural pest or damage, micro or macro. About this awkward and hard-to-digest truth for many 'believers,' I suppose it will clarify into another separate paper.

In these circumstances, are we still talking about the vanity reluctance of religion to step aside from the claim of saving the body and to give Science the role and the right to deal with this aspect in this situation? In no case! It needs to fulfill this natural approach and follow the standard procedure in such dimension, otherwise, it would be like asking engineering leave to religion the transportation just because it testifies about saints that walked on water or flew in the sky.

Thus, the only coherent message I would like to hear now from 'religion' in this regard would be only 'repent, for the Kingdom is coming', or something similar. This type of message has always been closely following the natural deserters at all times. Either we are talking about global ones like Noah's flood, or private one as Sodom, Nineveh or John the Baptist with Israel before Christ's coming. I do not imply that this is an apocalyptic event (Revelation 2:16), nor that such an event is concealing a specific coded call. However, whatever this event is/means 
in God's iconomy, this message should be strongly and firmly address from religion(s) and 'on behalf of God', since there is no evidence that any mass-destroying event has ever had God's pedagogy towards anything else but repenting.

\section{CONCLUSION}

Regardless the color of confession, the level of pandemic amplitude, cases reported by illnesses or deaths, despite the early or late moment of the local epidemic outbreak, there is now no doubt that all major religious confessions and their local communities have taken the measure of prevention for the spread of the new Coronavirus in the Winter-Spring of 2020. However, contrary to social expectations, there were still too few confessions that took precaution measures for protecting their followers prior to the governmental constraint. On the other hand, no religious organism was exempted from splitting the internal opinions into fractions pro and against these measures, respectively pro and against the unconditional submission to them by the respective religion; thy were generally named 'progressives and liberals' vs 'traditionalists and conservators'. Also, besides taking the civil and social measures imposed by each State in fighting the outbreak, each religious leadership has finally taken account of these standard impositions despite the virulent opposition of their traditionalist fraction.

As mentioned in the text above, 'the apple of discord' took diverse forms and target, but the general view of those against impositions was that there is a plot from the secular world against religion and its manifestation and these social distancing measures should not be followed in regard to manifesting religiousness since they have divine protection. Regardless the religious color, all conservator factions worldwide argued the same things, mostly underlining God's assistance to His followers, 'intangibility' from harmful worldly factors for those who 'really believe', divine protection offered to those in need if asked with strong faith, or lately, everlasting coronation if being persecuted on religious grounds in modern times for the same reasons for prohibiting the manifestation of religiosity. This conservator view was very virulent and rampant in all Media, moreover since the other faction, of the 'open-minded' theologians, have received support from the laity, the unbelievers and the atheists, and even from those who are usually against religious manifestations. In this conjunction, it seems quite likely that the pacification of the liberal theologians with the non-believers very easy passes as a secularized attempt to emancipate and relax religious customs, rather than a rational attempt to protect parishioners from a nondiscriminatory virus. That is why, until the beginning of this pandemic outbreak (it is quite an assumption at this moment since we are still experiencing it and its social effects, at 13.4.2020) the formers couldn't get over their opinion and understand the vital necessity of these precaution measures and give up to the hasty criticism against the society that is fighting blindly and with its hands tied against an atypical and unpredictable enemy.

As stated earlier, in my opinion, I would very much like for the leadership in each religion and ideally for all religions to come up with a discerning statement, considering that both the State and the Church (i.e., religion) are looking for the welfare of their common members. Also, while correctly considering its position and role in this world, religion should assume its spiritual guidance of man, in addition to that fairly and honestly surrender to Science its role and position on earthly aspects aiming the well-being of their mutual members. Religion should relinquish thus to its pretend of extending its expertise over the areas of living that 
are in no case of religious competence and purpose because otherwise we are not overpassed the medieval conflict between Science and Religion, a conflict meant to weaken the position and the work to each of the two arms of human knowledge.

In the worst scenario, the unique and concerted message any religious conservative party would be entitled to give in these circumstances would be on the one hand directed towards a universal prayer, even private but ensconced by religious leadership, to God for the forgiveness of the mistakes of humanity struck so deeply and unanimously. On the other hand, it should deliver the call of all humanity to repentance, to profound change, in rethinking the position we have towards the surrounding nature that we have forced to defend with the weapons it has at its disposal to free itself from the despotic yoke of man. In no case, we should take this event of global proportions and indiscriminative impact upon human lives as a threat from the devil or a secret conspirator against religiousness and its free practice and fight against these imaginary, absurd 'enemy' and protest against rational governance.

\section{REFERENCES}

[1] https://qz.com/1808390/religion-is-at-theheart-of-koreas-coronavirus-outbreak/

[2] https://abc13.com/5976098/

[3] https://basilica.ro/patriarhia-romana-masurisanitare-si-spirituale-in-timp-de-epidemie/

[4] https://www.theguardian.com/world/2020/ mar/11/what-is-a-pandemic-coronaviruscovid-19-who, 11.03.2020.

[5] Vivian Yee, "In a Pandemic, Religion Can Be a Balm and a Risk", in The NY Times, March 22, 2020. URL https://www. nytimes.com/2020/03/22/world/middleeast/ coronavirus-religion.html, accessed 25.3.2020

[6] Ibidem.

[7] Kali Robinson, "How Are Major Religions
Responding to the Coronavirus?", in CFR (Council on Foreign Relations), March 19, 2020. https://www.cfr.org/in-brief/how-aremajor-religions-responding-coronavirus, 25

[8] Harmeet Kaur, "How religious communities are modifying traditions to prevent coronavirus spread", in CNN, March 12, 2020. URL: https://edition.cnn.com/2020/03/06/world/ religion-modify-traditions-coronavirus-trnd/ index.html, accessed 25.3.2020.

[9] https://www.theguardian.com/world/2020/ mar/14/religious-festivals-cancelled-orscaled-back-due-to-coronavirus

[10] https://www.mccy.gov.sg/about-us/news-andresources/press-statements $/ 2020 / \mathrm{mar} /$ covid19-mccy-advisory-on-religious-activities

[11] https://time.com/5796035/coronavirus-saudiarabia-iran-islam-mecca/.

[12] Yaron Steinbuch, “Bethlehem's storied Church of the Nativity closes amid coronavirus fears", in New York Post, URL https://nypost. com/2020/03/05/bethlehems-storied-churchof-the-nativity-closes-amid-coronavirusfears/, 29.3.2020.

[13] https:/www.aljazeera.com/news/2020/04/ extraordinary-easter-jerusalem-coronavirusclosures-200410135058514.html?utm source $=$ website\&utm medium $=$ article page\&utm_campaign $=$ read_more_links, 10.4.2020.

[14] https://www.arabnews.com/node/1656171/ world, 14.4.2020.

[15] https://time.com/4551523/venice-ghettohistory/

[16] Susan L. Einbinder, After the Black Death: Plague and Commemoration Among Iberian Jews (University of Pennsylvania Press, 2018). ISBN 9780812250312

[17] Assoc. prof. Patriciu Vlaicu in Cristi Șelaru, "Adevărul despre decizia Bisericii (Eng. The truth about the Church's decision)", in STIRIPESURSE.RO. https://www. stiripesurse.ro/adevarul-despre-deciziabisericii 1435459.html, accessed 18.3.2020.

[18] Ron Synovitz, "Coronavirus Vs. The Church: Orthodox Traditionalists Stand Behind The Holy Spoon", in RadioFreeEurope RadioLiberty, URL: https://www.rferl. org/a/coronavirus-vs-the-church-orthodox- 
traditionalists-stand-behind-the-holyspoon/30492749.html, accessed 4.4.2020.

[19] Ibidem.

[20] Robin Forestier-Walker, "Georgia priests bless Tbilisi city in bid to contain COVID-19”, in https://www.aljazeera. com/. URL: https://www.aljazeera.com/ news/2020/03/georgia-priests-bless-tbilisicity-bid-covid-19-200318105909005.html, accessed 18.03.2020.

[21] Alex Woodward, "US priest who shook hands with more than 500 worshippers infected with virus", in INDEPENDENT, New York, Monday 9 March 2020. Retrieved from URL https://www.independent.co.uk/news/world/ americas/coronavirus-us-priest-washingtondc-quarantine-timothy-shake-handschurch-a9388561.html, accessed 18.03.2020. see Annex 5.

[22] https://www.avvenire.it/attualita/pagine/ coronavirus-i-preti-morti-emilia-lombardia, accessed 5.4.2020.

[23] https://www.goarch.org/-/encyclical-covid19-pandemic, 6.03.2020.

[24] Ibidem.

[25] Joseph Ernest Renan, The History of the Origins of Christianity Book V - The Gospels. (DEVOTED Publishing, 2017) 12-13.

[26] Seventh-day Adventists' beliefs about medical care made headlines in 2014 when a British couple, Nkosiyapha and Virginia Kunene, pleaded guilty to manslaughter in the death of their 5-month-old son from severe vitamin D deficiency, or rickets. Although the religion's lifestyle includes a vegetarian diet and abstinence from alcohol, tobacco and other drugs, the Kunenes' extreme views on rejecting medical care are not shared by their church. Sandee LaMotte, “"Inoculate yourself with the word of God': How religion can limit medical treatment", in CNN Heath edition, February 7, 2018. Retrived from https:// edition.cnn.com/2018/02/07/health/religionmedical-treatment/index.html, accessed 17.03.2020.

[27] Sophism, circular definition.

\section{BIOGRAPHY}

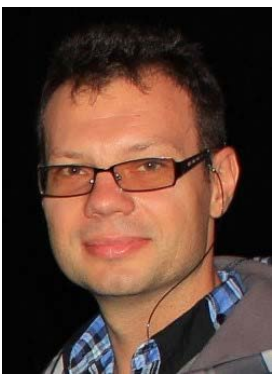

Tudor Cosmin CIOCAN, born in Constantal Romania in 1977, attended several theological and psychological schools (BA, MB, Ph.D.), obtained his Ph.D. in Missiology and Doctrinal Theology in 2010. He was ordained as an orthodox priest in 2002. Highschool teacher from 1998, then Professor assistant and Lecturer from 2012, he has written more than 65 articles on theology and psychology, along with 4 single-author books in the past two decades. In 2013 he started a multidisciplinary program aiming to engage scholars from different files into friendly and academic debates with theology, and in the same year, a Research Center was founded in Ovidius University with researchers from 11 fields. In less than one year, he managed to gather people from around the globe around this idea, and thus the Dialogo Conferences project has started. In 2014 he received a Fulbright scholarship, and spent the summer in California along with four other states in the USA, gathering data and understanding how religious pluralism is possible at a high level of involvement; in the meanwhile he made friends from many different countries and religions that are now involved in this project or another, helping in his endeavor. Now he researches and teaches in this direction, towards building bridges between science and theology on the one side, and interfaith dialogue, on the other hand. 